\author{
International Journal of Veterinary Sciences Research \\ 2021 Vol. 6, No. 2, pp. 14-18. \\ $\operatorname{ISSN}(e): 2410-9444$ \\ $\operatorname{ISSN}(p): 2413-8444$ \\ DOI: 10.18488/journal.110.2021.62.14.18 \\ (C) 2021 Conscientia Beam. All Rights Reserved. \\ check for
updates
}

\title{
PREVALENCE OF KETOSIS DETECTED BY AN ELECTRONIC COW SIDE TEST AND ITS IMPACT TO DAYS OPEN ON DAIRY COWS
}

\author{
Duricic Drazen ${ }^{1+}$ \\ Bacan Iva ${ }^{2}$ \\ (D) Samardzija Marko \\ 'Mount-Trade D.O.O., Garesnica, Croatia; Clinic for Reproduction and \\ Obstetrics, Faculty of Veterinary Medicine, Zagreb, Croatia. \\ 'Email: dduricic19@gmail.com Tel: +385(0)914859142 \\ ${ }^{2,3}$ Clinic for Reproduction and Obstetrics, Faculty of Veterinary Medicine, \\ Zagreb, Croatia. \\ EEmail:iva.bacan@gmail.com \\ ${ }^{s}$ Email: smarko@,vef.unizg.hr Tel: +385(0)912390157
}

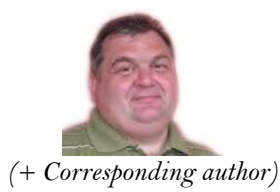

ABSTRACT

Article History

Received: 12 October 2021 Revised: 16 November 2021 Accepted: 30 November 2021 Published: 14 December 2021

\section{Keywords}

Cows

Days open

Ketosis

Diagnosis

BHBA

Test.

\begin{abstract}
The study aimed to resolve and confirm the previous results of subclinical and clinical ketosis prevalence in northwestern Croatia detected by an electronic cow side test and its impact on days open in dairy herds. Cows $(\mathrm{N}=559)$ 2-8 years old from 96 farms located in northwestern Croatia were included in the study. The average milk yield was $7327.80 \pm 968.21 \mathrm{~kg}$. The cows were classified into two separate groups: ketotic cows group KET $(\mathrm{n}=73)$ with BHBA blood concentration of $\geq 1.4 \mathrm{mmol} / \mathrm{L}$, and negative NEG $(\mathrm{n}=486)$ group with serum BHBA level of $<1.4 \mathrm{mmol} / \mathrm{L}$. One droplet of blood from the caudal vein was collect from randomly selected cows in the period 7 to 15 days after parturition. BHBA level determined with Precision Xceed BHBA devices. The period from parturition to first insemination (days open to the first (artificial) insemination, DOFI) was shorter in NEG than in the POS group (110.56 10.65 days vs.114.82 12.23 days, respectively) such as period from parturition to successful

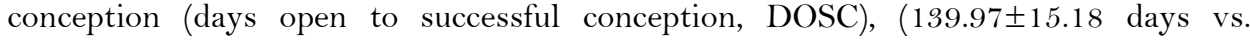
$127.99 \pm 15.87$ days, respectively). The prevalence of clinical and subclinical ketosis was $15.02 \%$. Ketosis significantly prolonged days open to first artificial insemination and days open to successful conception in cows from northwestern Croatia.
\end{abstract}

Contribution/Originality: This study documents and confirms the previous results of subclinical and clinical ketosis prevalence in northwestern Croatia detected by an electronic cow side test and its impact to prolonged days open to first artificial insemination and days open to successful conception in dairy herds.

\section{INTRODUCTION}

In dairy cows, ketosis present a relatively frequent metabolic disorder, which occurs around calving (usually 24 week after claving) manifested by increased levels of ketones(beta-hydroxybutyric acid (BHBA), acetoacetate, and acetone). Increased concentrations of ketones are found in milk, urine and blood [1, 2]. Milk production increases rapidly after calving, so cows are unable to consume adequate energy to sustain basal metabolism and increased needs due to lactation, causing them to be in a negative energy balance (NEB).

A NEB state induces the cow to mobilise body's reserves and non-esterified fatty acids (NEFA) from blood are converted to glucose. This process takes place in the liver and is called gluconeogenesis, and serves to compensate for the lack of nutrient intake. In the preventative measures to reduce the risk of ketosis, reducing the dept and 
duration of negative energy balance (NEB) is crucial [3, 4]. Depending on the presence or absence of clinical signs, ketosis can be clinical or subclinical. Cows affected by clinical ketosis (CK) may have some of the following clinical symptoms: anorexia, lethargy, reduce milk production, nervous symptoms, dullness, and obvious weight loss [5, 6]. The predominant ketone body in ruminant blood is BHBA which is essential for the diagnosis of subclinical ketosis. Subclinical ketosis (SK) is characterized by absence of clinical signs and increased BHBA level more than 1.4 $\mathrm{mmol} / \mathrm{L}[7,8]$. Most ketosis tests are most commonly based on sodium nitroprusside reaction with acetoacetate or acetone in urine or milk [9]. For the diagnosis of ketosis, hand-held ketone body monitoring instruments (similar to those used by diabetics) to accurately quantify the levels of BHBA in cows are used, nowadays. Iwersen, et al. [10] the first reported an electronic device for BHBA levels determination in humans (MediSense Precision, Abbott, Abingdon, UK) used for BHBA blood levels determination in dairy cows. Previous studies [10, 11] were confirmed a relatively fast and affordable method of detecting dairy cows with subclinical ketosis as very accurate and reliable because the values obtained spectrophotometrically in the laboratory were almost identical to those obtained by electronic device (Precision Xceed BHBA (Abbot)) in field conditions [12]. Subclinical (and clinical) ketosis causes enormous losses worldwide on dairy farms due to reduced milk production, and diagnostic, prevention, treatment and veterinary costs. Detection of ketotic cows as early as possible allows intervention on time and reduces the possibility of lower milk production [13]. In the first two weeks after parturition, ketosis is associated with an increased risk of many digestive (abomasum displacement) and reproductive ((endo) metritis, prolonged postpartum anovulatory period), more severe mastitis and decreased milk production. The prevalence of subclinical ketosis in dairy herds during early lactation is estimated at $7.5 \%-14 \%[14,15]$ while in Croatia at $15.8 \%$ [16].

The study aimed to resolve and confirm the previous results of the subclinical and clinical ketosis prevalence in northwestern Croatia detected by an electronic cowside test and its impact on days open in dairy herds.

\section{MATERIALS AND METHODS}

\subsection{Animals}

Cows ( $\mathrm{N}=559)$ 2-8 years old with average parity 2.72 1.37 , from 96 farms located in the northwestern Croatia were included in the study. The most of cows were housed in a free-standing stables on straw bedding. There were 12 and 175 dairy cow on each farm. The feeding consisted of hay, grass and corn silage, and concentrate. All lactating cows were milked 2 times a day. The milk yield on all farms togheter was $7327.80 \pm 968.21 \mathrm{~kg}$ in 305 days of lactation. The cows were classified into two separate groups: ketotic cows group KET ( $\mathrm{n}=73$ ) with BHBA blood concentration of $\geq 1.4 \mathrm{mmol} / \mathrm{L}$, and negative NEG $(\mathrm{n}=486)$ group with serum BHBA level of $<1.4 \mathrm{mmol} / \mathrm{L}$. Blood samples for analysis were taken from the caudal vein by sterile needle. One droplet of blood was collect from randomly selected cows in the period 7 to 15 days after parturition. Precision Xceed BHBA devices and test strips (Abbot) were used according to the instructions for use of the device. Each animal was tested only once. All cows suffering from any other disease than ketosis or those treated in the transition period before sampling were excluded from the study. Total lactations data were calculated by Croatian Agency of Agriculture and Food according International Committee for Animal Recording (ICAR) protocols by AT4 methods milk yield (during 305 days of lactation) was determined. After calving, all cows were vaginally and rectally examined. After the heat was observed, the cows were artificially inseminated by experienced inseminators with frozen-thawed semen. All cows were examined 1.5 months after insemination with transrectal ultrasonography until pregnancy was confirm. Reproductive performance and culling data of individual animals were collected to the end of lactation (305 days) of each cow in the study. Data about lactation, parity, period from parturition to the first artificial insemination (days open to first (artificial) insemination, DOFI) and period from parturition to successful conception (days open to successful conception, DOSC). 


\subsection{Statistical Analysis}

All data were analysed using the statistical program StatSoft Tulsa, Statistica, 7.1, using ANOVA and Tukey's test post hoc analysis including days open until successful conception (DOSC) and days open until the first insemination (DOFI), and statistically significant results were considered $\mathrm{P}<0.05$.

\section{RESULTS}

Average BHBA level differed between groups Table 1. In NEG group of cows average BHBA was 0.63 \pm 0.19 $\mathrm{mmol} / \mathrm{L}$, while in POS was $1.85 \mathrm{mmol} / \mathrm{L}$. Only $3.09 \%$ (15/559) had clinical signs of ketosis. In both groups, the average amount of milk in 305 days of lactation was about $7300 \mathrm{~kg}$ of milk. The period from parturition to the first insemination (days open to first (artificial) insemination, DOFI) was shorter in NEG than in KET group

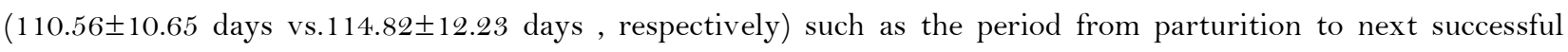
conception (days open to successful conception, DOSC), (139.97 \pm 15.18 days vs. $127.99 \pm 15.87$ days, respectively) Table 1 .

Table-1. The BHBA levels, milk yields, days open to first insemination (DOFI) and days open to successful conception (DOSC) in NEG (negative) group and KET (ketotic) group of cows suffering ketosis.

\begin{tabular}{|c|c|c|c|c|c|c|c|}
\hline & \multicolumn{3}{|c|}{ NEG } & \multicolumn{3}{|c|}{ POS } & TOTAL \\
\hline $\mathrm{N}$ & \multicolumn{3}{|c|}{486} & \multicolumn{3}{|c|}{73} & 559 \\
\hline & $\mathrm{M} \pm \mathrm{SEM}$ & MIN & MAX & $\mathrm{M} \pm \mathrm{SEM}$ & MIN & MAX & $\mathrm{M} \pm \mathrm{SEM}$ \\
\hline $\mathrm{BHBA}(\mathrm{mmol} / \mathrm{L})$ & $0.63 \pm 0.19^{\mathrm{a}}$ & 0.2 & 1.3 & $1.85 \pm 0,37^{\mathrm{b}}$ & 1.4 & 2.3 & $0.88 \pm 0.45$ \\
\hline MILK YIELD (kg) & $7327.96 \pm 970.70^{\mathrm{a}}$ & 4780 & 9440 & $7281.64 \pm 934.13^{\mathrm{a}}$ & 4780 & 9250 & $7327.80 \pm 968.21$ \\
\hline DOFS (days) & $110.56 \pm 10.65^{\mathrm{a}}$ & 86 & 164 & $114.82 \pm 12.23^{\mathrm{b}}$ & 88 & 168 & $112.69 \pm 10.78$ \\
\hline DOP (days) & $127.99 \pm 15.87^{\mathrm{a}}$ & 89 & 213 & $139.97 \pm 15.18^{b}$ & 93 & 169 & $129.38 \pm 16.45$ \\
\hline
\end{tabular}

\section{DISCUSSION}

Ketosis occurs in a transition period and is associated with many transition diseases in a high-producing dairy cows [17]. The prevalence of clinical (CK) and subclinical ketosis (SCK) varies widely on farms in Europe. Almost $39 \%$ of all dairy cows are presumed to suffer from ketosis. In some European countries the prevalence of herd ketosis was 31 to 53\% (31\% in Italy and the United Kingdom, $43 \%$ in Germany, $46 \%$ in the Netherlands and 53\% in France) while the prevalence of subclinical ketosis at herd level ranged from $34 \%$ to $63 \%$ (34\% in the Czech Republic, Austria, 40\% in Hungary and 63\% in Poland). Overall, only 11.6\% had clinical and 40\% of dairy cows had subclinical ketosis [18]. In India, prevalence rate for CK was between $27.2 \%$ and $36.7 \%$, while 9.6\% in SCK [19]. In the surveyed countries of the world on different continents (Africa, America, Asia, Australia, and Europe), the average prevalence of SCK was $24.1(8.3-40.1) \%$ [20] despite to differences in production systems and different livestock farming, SCK prevalence was similar. In the continental part of Croatia, the prevalence of SCK was $15.8 \%$ in Holstein cows due to lower milk production than in previously mentioned countries [12, 16]. In our study prevalence was even lower $15.02 \%$ for CK and SCK. More than $80 \%$ of cows $(58 / 73)$ with BHBA level $\geq 1.4$ $\mathrm{mmol} / \mathrm{L}$ were without clinical signs, in our study.

Among a number of parameters to assess the reproductive performance of cows (intercalving period, conception rate, pregnancy rate, etc) in this study period from parturition to first insemination (days open to first insemination, DOFI) and period from parturition to successful conception (days open to successful conception, DOSC) were used. In the aim of improving and increasing production farmers around the world want to shorten the service period or days open in dairy cows. It is well-known that ketosis have long-lasting effects and reduces reproductive efficiency in cows.

The success of conception in the first insemination after calving was 4.3 times lower in cows suffering from ketosis compared to cows in which BHBA was in the physiological range [21]. Days open to first insemination for 
Holstein cows was $111.55 \pm 3.73$ days in Turkey [22] similar to DOFS for healty cows in our study, and DOP for Holstein cows in Turkey was $149.60 \pm 4.36$ days which is 10 days longer for POS group of cows in our study.

\section{CONCLUSSION}

The prevalence of clinical and subclinical ketosis was $15.02 \%$. Ketosis significantly prolonged days open to first artificial insemination and days open to the next successful conception in dairy cows in the northwestern Croatia. In order to shorten the days open, cows suffering from ketosis must be diagnosed as soon as possible and treated immediately. It can be used a precise electronic device BHBA meter as an effective tool for diagnosed ketosis in dairy herds.

Funding: This study received no specific financial support.

Competing Interests: The authors declare that they have no competing interests.

Acknowledgement: All authors contributed equally to the conception and design of the study.

\section{REFERENCES}

[1] T. F. Duffield, D. F. Kelton, K. E. Leslie, K. D. Lissemore, and J. H. Lumsden, "Use of test day milk fat and milk protein to detect subclinical ketosis in dairy cattle in Ontario," The Canadian Veterinary Journal, vol. 38, pp. 713-718, 1997.

[2] Z. Zhang, G. Liu, H. Wang, X. Li, and Z. Wang, "Detection of subclinical ketosis in dairy cows," Pakistan Veterinary Journal, vol. 32, pp. 156-160, 2012.

[3] T. Overton and M. Waldron, "Nutritional management of transition dairy cows: Strategies to optimize metabolic health," Journal of Dairy Science, vol. 87, pp. E105-E119, 2004. Available at: https://doi.org/10.3168/jds.s00220302(04)70066-1

[4] P. Kočila, A. Janžek, D. Gračner, T. Dobranić, D. Đuričić, N. Prvanović, N. Filipović, G. G. Gregurić, L. Bedrica, F. Marković, M. Horvat, and M. Samardžija, "Progesterone concentration and energy balance influence on dairy cows with different milk yield during puerperium," Veterinarian Review, vol. 68, pp. 266-274, 2013.

[5] M. A. Youssef, S. A. El-Khodery, W. M. El-deeb, and W. E. Abou El-Amaiem, "Ketosis in buffalo (Bubalus bubalis): Clinical findings and the associated oxidative stress level," Tropical Animal Health and Production, vol. 42, pp. 17711777, 2010. Available at: https://doi.org/10.1007/s11250-010-9636-9

[6] I. Folnožić, R. Turk, D. Đuričić, S. Vince, J. Pleadin, Z. Flegar-Meštrić, H. Valpotić, T. Dobranić, D. Gračner, and M. Samardžija, "Influence of body condition on serum metabolic indicators of lipid mobilization and oxidative stress in dairy cows during the transition period," Reproduction in Domestic Animals, vol. 50, pp. 910-917, 2015. Available at: https://doi.org/10.1111/rda.12608

[7] L. Andersson, "Subclinical ketosis in dairy cows," Veterinary Clinics of North America: Food Animal Practice, vol. 4, pp. 233-251, 1988.

[8] J. Carrier, S. Stewart, S. Godden, J. Fetrow, and P. Rapnicki, "Evaluation and use of three cowside tests for detection of subclinical ketosis in early postpartum cows," Journal of Dairy Science, vol. 87, pp. 3725-3735, 2004. Available at: https://doi.org/10.3168/jds.s0022-0302(04)73511-0

[9] S. LeBlanc, "Monitoring metabolic health of dairy cattle in the transition period," Journal of Reproduction and Development, vol. 56, pp. S29-S35, 2010. Available at: https://doi.org/10.1262/jrd.1056s29

[10] M. Iwersen, U. Falkenberg, R. Voigtsberger, D. Forderung, and W. Heuwieser, "Evaluation of an electronic cowside test to detect subclinical ketosis in dairy cows," Journal of Dairy Science, vol. 92, pp. 2618-2624, 2009. Available at: https://doi.org/10.3168/jds.2008-1795

[11] J. McArt, D. Nydam, and G. Oetzel, "Epidemiology of subclinical ketosis in early lactation dairy cattle," Journal of Dairy Science, vol. 95, pp. 5056-5066, 2012. Available at: https://doi.org/10.3168/jds.2012-5443 
[12] D. Đuričić, S. Vince, D. Gračner, I. Folnožić, I. Križek, and M. Samardžija, "Comparison of two different determination methods of subclinical ketosis prevalence in Holstein cows in Northwestern Croatia," Veterinary Survey, vol. 70, pp. 55$59,2015$.

[13] T. Duffield, K. Lissemore, B. McBride, and K. Leslie, "Impact of hyperketonemia in early lactation dairy cows on health and production," Journal of Dairy Science, vol. 92, pp. 571-580, 2009. Available at: https://doi.org/10.3168/jds.20081507

[14] T. Geishauser, K. Leslie, J. Tenhag, and A. Bashiri, "Evaluation of eight cow-side ketone tests in milk for detection of subclinical ketosis in dairy cows," Journal of Dairy Science, vol. 83, pp. 296-299, 2000. Available at: https://doi.org/10.3168/jds.s0022-0302(00)74877-6

[15] F. Enjalbert, M. Nicot, C. Bayourthe, and R. Moncoulon, "Ketone bodies in milk and blood of dairy cows: Relationship between concentrations and utilization for detection of subclinical ketosis," Journal of Dairy Science, vol. 84, pp. 583589, 2001. Available at: https://doi.org/10.3168/jds.s0022-0302(01)74511-0

[16] S. Vince, D. Đuričić, H. Valpotić, D. Gračner, I. Folnožić, B. Špoljarić, P. Sobiech, and M. Samardžija, "Risk factors and prevalence of subclinical ketosis in dairy cows in Croatia," Veterinary Archives, vol. 87, pp. 13-24, 2017.

[17] T. Vanholder, J. Papen, R. Bemers, G. Vertenten, and A. Berge, "Risk factors for subclinical and clinical ketosis and association with production parameters in dairy cows in the Netherlands," Journal of Dairy Science, vol. 98, pp. 880-888, 2015. Available at: https://doi.org/10.3168/jds.2014-8362

[18] A. C. Berge and G. Vertenten, "A field study to determine the prevalence, dairy herd management systems, and fresh cow clinical conditions associated with ketosis in Western European dairy herds," Journal of Dairy Science, vol. 97, pp. 2145-2 154, 2014. Available at: https://doi.org/10.3168/jds.2013-7163

[19] S. Biswal, D. C. Nayak, and K. K. Sardar, "Prevalence of ketosis in dairy cows in milk shed areas of Odisha state, India," Veterinary World, vol. 9, pp. 1242-1247, 2016. Available at: https://doi.org/10.14202/vetworld.2016.1242-1247

[20] N. Brunner, S. Groeger, J. Canelas Raposo, R. M. Bruckmaier, and J. J. Gross, "Prevalence of subclinical ketosis and production diseases in dairy cows in Central and South America, Africa, Asia, Australia, New Zealand, and Eastern Europe," Translational Animal Science, vol. 3, pp. 84-92, 2019. Available at: https://doi.org/10.1093/tas/txy 102

[21] A. J. Rutherford, G. Oikonomou, and R. F. Smith, "The effect of subclinical ketosis on activity at estrus and reproductive performance in dairy cattle," Journal of Dairy Science, vol. 99, pp. 4808-4815, 2016. Available at: https://doi.org/10.3168/jds.2015-10154

[22] S. Cilek, "Reproductive traits of Holstein cows raised at polatli state farm in Turkey," Journal of Animal and Veterinary Advances, vol. 8, pp. 1-5, 2009.

Views and opinions expressed in this article are the views and opinions of the author(s), International Journal of Veterinary Sciences Research shall not be responsible or answerable for any loss, damage or liability etc. caused in relation to/arising out of the use of the content. 